Володимир Колесник, кандидат технічних наук, старший науковий співробітник ORCID ID 0000-0002-6323-7748

Руслан Серветник, кандидат педагогічних наук, старший науковий співробітник ORCID ID 0000-0001-5624-4889 Національний університет оборони України імені Івана Черняховського

\title{
ТЕОРЕТИЧНІ ОСНОВИ МОДЕЛЮВАННЯ ПРОФЕСІЙНОӤ ДІЯЛЬНОСТІ ЗДОБУВАЧІВ ВИЩОЇ ОСВІТИ СТУПЕНЯ ДОКТОРА ФІЛОСОФІЇ В АД'ЮНКТУРІ ВІЙСЬКОВОГО ЗАКЛАДУ ВИЩОЇ ОСВІТИ
}

У статті окреслено теоретичні основи моделювання професійної діяльності здобувачів вищьӧ освіти ступеня доктора філософії та можливі шляхи їх впровадження при організації підготовки ад'юнктури у вищих військових закладах вищої освіти (наукових установах).

Ключові слова: заклад вищої освіти; підготовка здобувачів вищої освіти ступеня доктора філософії; нормативно-правові документи; моделі освіти.

Постановка проблеми. Сучасні тенденції розвитку Збройних Сил України (далі - ЗС України), висувають нові вимоги до підготовки здобувачів вищої освіти ступеня доктора філософії, а це означає, що пріоритетом $\epsilon$ не просте накопичення знань та предметних умінь і навичок, а підготовка висококваліфікованого військового фахівця відповідного рівня та профілю, конкурентоздатного, компетентного, який вільно володіє професією військового та орієнтується в суміжних галузях діяльності, готового до постійного професійного росту, соціальної та професійної мобільності.

Відповідно до нормативно-правової бази України, підготовка здобувачів вищої освіти ступеня доктора філософії передбачає здобуття особою теоретичних знань, умінь, навичок та інших компетентностей, достатніх для продукування нових ідей, розв'язання комплексних проблем у галузі професійної та/або дослідницько-інноваційної діяльності, оволодіння методологією наукової та педагогічної діяльності, а також проведення власного наукового дослідження, результати якого мають наукову новизну, теоретичне та практичне значення $[1 ; 2 ; 3]$.

Організацію підготовки здобувачів вищої освіти ступеня доктора філософії, майбутніх наукових працівників i науково-педагогічних працівників (далі - НП та НПП) для ЗС України, здійснюють науковоорганізаційні підрозділи в ад'юнктурі військових закладів вищої освіти та/або наукових установ (далі - В3ВО). У Національному університеті оборони України імені Івана Черняховського ці функції покладено на 
науковий відділ підготовки та атестації науково-педагогічних кадрів науково-методичного центру організації наукової та науково-технічної діяльності.

Зростання ролі людського фактору у військово-професійній діяльності вимагає від підготовки здобувачів вищої освіти ступеня доктора філософії в ад'юнктурі не тільки професійної компетентності, але й грунтовної підготовленості та, перш за все, здатності визначати та розв'язувати соціально значущі системні проблеми у певній галузі діяльності, які $\epsilon$ ключовими для забезпечення стійкого розвитку та вимагають створення нових системоутворюючих знань і прогресивних технологій. [4].

Моделювання професійної діяльності здобувачів вищої освіти ступеня доктора філософії у ад'юнктурі ВЗВО здійснюється під час їх підготовки, де відбувається уявне розкладання реальної системи - оригіналу на елементи, які тим чи іншим чином пов'язані між собою, що зумовлюють виконання визначеної складної функції, яка і можлива лише завдяки конструкції, що складається 3 великої кількості взаємопов'язаних елементів, які взаємодіють один 3 одним. [5, с. 6].

На нашу думку, саме моделювання професійної діяльності дозволяє адекватно i цілісно відобразити в модельних уявленнях сутність, найважливіші якості і компоненти системи (в нашому випадку - підготовку здобувачів вищої освіти ступеня доктора філософії в ад’юнктурі закладу вищої освіти ), одержати інформацію про їі минулий, теперішній і майбутній стан, можливості та умови побудови, функціонування і розвитку.

Аналіз останніх досліджень і публікацій. Оскільки Україна (2005 р.) стала учасником Болонського процесу, проблема модернізації ад'юнктури набула значної актуальності, про що свідчить поява праць 3 цієї тематики: в площині методологічного осмислення проблеми - А.М. Алексюка, В.П. Андрущенка, В.Г. Кременя, В.К. Майбороди, О.Я. Савченко та ін.; тенденції підготовки аспірантів в Україні в XX - XI ст. - I. Регейло; аспекти компаративного аналізу докторської освіти в зарубіжних країнах В.І. Луговий, В.С. Лутай, Л. Лобанова, О. Поживілова, Ж.В. Таланова; розвиток наукового потенціалу - М. Бірюкова; нормативно-правове регулювання підготовки та атестації наукових і науково-педагогічних кадрів в Україні - Л.В. Лисенко, Б.А. Пережняк, О.С. Попович, В.О. Чмига та ін.

Ці праці, беззаперечно, зробили вагомий внесок у розвиток військовопедагогічної науки в Україні. Але в той же час, практично відсутні праці, в яких досліджуються проблеми моделювання професійної діяльності здобувачів вищої освіти ступеня доктора філософії у ад’юнктурі ВЗВО.

Мета статті полягає у обгрунтуванні теоретичних основ моделювання професійної діяльності здобувачів вищої освіти ступеня доктора філософії у ад'юнктурі ВЗВО, розроблені методичних і практичних рекомендацій підготовки військових кадрів вищої кваліфікації.

Виклад основного матеріалу. Сутність реформи військової освіти полягає у тому, щоб одночасно 3 реорганізацією військової компоненти 
створити відповідну їй систему підготовки офіцерських кадрів вищої кваліфікації, яка буде відповідати новій структурі і завданням ЗС України та буде спроможна забезпечувати професійне виконання завдань за призначенням. У науковій педагогічній літературі з проблем моделювання подаються різні класифікації моделей. Наприклад, пропонується диференціювати всі можливі види моделей на підставі таких важливих критеріїв: за класами задач, за класами об'єктів, за формою подання інформації [6, с. 144]. Серед виділених таким чином модельних конструкцій, поруч із класичними моделями (технологічними, кібернетичними, математичними, інформаційними), існують чимало специфічних, своєрідних, a саме: аналогові, ізоморфні, аналітичні та графоаналітичні, алгоритмічні, імітаційні, динамічні, імовірнісно-статистичні, ідентифікаційні, проектні, людино-машинні, моделі процесів, систем керування та ін.

До основних видів моделей, що використовуються або можуть бути використані у професійної діяльності здобувачів вищої освіти ступеня доктора філософії в ад'юнктурі віднесено:

Функиіональні моделі, які імітують спосіб поведінки певної системи. Останнім часом з'явилося багато автоматичних пристроїв, що імітують елементи поведінки живих організмів. Наприклад, це можуть бути різноманітні спроби змоделювати за допомогою електронних засобів певні нервові та психічні функції живих організмів, процеси мислення тощо.

Уявні моделі, які широко використовуються в науково-теоретичних дослідженнях і в навчальному процесі.

Знакові моделі дають можливість подати в наочній формі складну структуру різних елементів і пояснити їхній взаємозв'язок у складних системах [7, с. 22-23]. Акцентуємо, що знак - це матеріальний предмет, процес, дія, які виконують у спілкуванні роль опонента і використовуються для отримання, зберігання, перетворення i передачі певної інформації. Вихідною знаковою системою вважається звичайна, природна мова. Серед немовних знаків виділяють знакові - копії (фотографіï), знаки ознаки (озноб - симптом хвороби), знаки-сигнали (дзвоник), знаки-символи і знаки спілкування (вся сукупність природних і штучних мов). До знаків штучних систем відносять різні кодові системи (абетка Морзе, коди машинних програм), знаки формул, криві, схеми, системи сигналізації. Будь-який знак функціонує тільки в системі знаків. Наука про побудову і функціонування знакових систем називається семіотикою.

Концептуальні моделі, які передбачають розроблення і використання моделей, сформованих у результаті спостереження та у процесі функціонування об'єкта; вони дозволяють оцінювати значимість цілісності, виявляти якості системи й отримувати інформацію про іiї стан, зумовлений структурою.

Логічні моделі будуються за допомогою апарату математичної логіки і використовуються для їх змістовної інтерпретації. 
Кібернетичні моделі формуються на основі співвідношень між вхідними і вихідними функціями для “чорного ящика”, який відображає досліджуване явище без розкриття його внутрішньої структури.

Квазіаналогові моделі та електронні моделі призначені для синтезу ланцюгів - моделей різних об'єктів. Наразі мають надзвичайно велике значення у вирішенні задач, що виникають у процесі проектування великих систем [8, с. 197].

А.О. Лігоџький виділяе три підходи до моделей, побудованих на різноманітних результатах підготовки фахівців. Перша модель передбачає його загально-психологічну підготовку, орієнтується на формування психологічної готовності до професійної діяльності. Підготовка фахівців за цією моделлю пов'язується із вивченням структури їхньої діяльності, науково-теоретичних основ професійного формування, рівня професійної кваліфікації. Зміст другої моделі становлять основні функції фахівця, оволодіння якими дає йому можливість успішно адаптуватися до професійної діяльності та виконувати різноманітні професійні дії. Третю модель побудовано на основі педагогічної майстерності фахівця та з урахуванням рівнів підготовленості тих, хто навчається, тобто того комплексу якостей особистості, який забезпечує ефективність управління процесами навчання та розвитку самореалізації особистості $[9$, с. 19].

У сфері освіти розробляються моделі, що використовуються 3 різноманітними цілями і на різних рівнях, а саме: освітні моделі і різні моделі освіти, моделі навчання і методичні моделі, а також моделі фахівця і моделі того, хто навчається. Ці моделі значною мірою визначають вимоги до моделювання процесів у військово-професійній освіті, тому коротко охарактеризуємо їх.

Освітньою моделлю називають логічно-послідовну систему відповідних елементів, які складаються із цілей освіти в широкому смислі слова, змісту освіти, моделювання навчальних планів і програм, окремих цілей керування діяльністю тих, хто навчається; моделі їх угруповання; методи контролювання і звітності; способи оцінювання діяльності НПП і тих хто навчається. Модель освіти як державно-відомчої організації розглядає освіту як самостійний напрямок народного господарства, що будується по відомчому принципу з твердим централізованим визначенням цілей, змісту, номенклатури навчальних закладів i навчальних дисциплін. В освіті використовуються ï певні моделі.

Традииійна модель освіти (Ж. Мажо, Л. Кро, Ж. Крапля, Д. Равич, Ч. Фін та $і н$.$) передбачає систематичну академічну освіту як спосіб передачі$ новому поколінню універсальних елементів культурної спадщини людської цивілізації, відповідно до концепції традиціоналізму, освітня система має розв'язувати проблему формування базових знань, навичок і умінь, що дозволяє індивіду як особистості перейти до їх самостійного засвоєння на більш високому рівні. 
Раціоналістична модель освіти (П. Блум, Г. Ганьє, Б. Скіннер та ін.) передбачає таку іiі організацію, яка у першу чергу забезпечує засвоєння знань, навичок і умінь, практичну адаптацію молодого покоління до умов суспільства. Останнє визначає обрані для засвоєння знання, навички та уміння. При цьому, відсутні такі елементи як творчість, самостійність, відповідальність, індивідуальність та ін., панує дух вузького утилітаризму, нав'язування НПП механічного і негнучкого способу педагогічної діяльності.

Феноменологічна модель освіти (А. Маслоу, А. Комбс, К. Роджерс) передбачає індивідуальний характер навчання з урахуванням індивідуальнопсихологічних особливостей тих хто навчається, уважне ставлення до їхніх інтересів і потреб, забезпечення реалізації інтелектуального й особистісного потенціалів у професійній діяльності.

Неінституиійна модель освіти (П.Гудман, Ж. Гудлед, Ф. Клейн, Дж. Холт, Л.Бернар та ін.) орієнтується на організацію освіти поза соціальними інститутами: на природі, за допомогою Інтернету, в умовах відкритих шкіл, дистанційного навчання тощо [10, с. 69].

У кожній 3 існуючих моделей освіти реалізуються відповідні моделі навчання розглядаються як комплекс, що складається 3 дидактичної основи педагогічної техніки, використовуваної в навчальному процесі [11, с. 110]. Наприклад, модель розвиваючого навчання (В.В. Давидов, В.В. Фляків та ін.) передбачає організацію освіти як особливої інфраструктури через кооперацію діяльності освітніх систем різних рангів, рівнів і типів.

Самореалізація того хто навчається в освітній системі має чіткі психологічно орієнтовані методичні моделі, що базуються на розробках закордонних і вітчизняних дослідників [12]. Деякі з них розглянемо нижче.

Вільна модель припускає, що учень за допомогою вчителя сам визначає інтенсивність і тривалість у часі навчальних занять, вільно планує час, самостійно вибирає засоби, методи, прийоми і форми навчання. Тверда система педагогічних впливів відсутня, підтримується імпровізація в дітей i вчителя в доборі змісту і способів навчання. Ключовим психологічним компонентом моделі $\epsilon$ “воля індивідуального вибору" (М. Штайнер, Ф. Кумбс, Ч. Сільберман, В. Біблер).

Особистісна модель має мету дати загальний розвиток тим, хто навчається, у тому числі пізнавальний, емоційно-вольовий, моральний i естетичний. Навчання здійснюється на високому рівні складності, при цьому створюється атмосфера довіри, варіативність навчального процесу 3 урахуванням індивідуальних особливостей особистості слухача. Ключовим психологічним елементом $є$ "цілісний особистісний розвиток того, хто навчається".

Розвиваюча модель націлена на перебудову навчальної діяльності для забезпечення теоретичного мислення, рефлексії, самостійності в рішенні різних навчальних завдань. Основна увага приділяється теоретичним знанням. Тому хто навчається пропонують нові засоби навчальної діяльності, наприклад, знакові моделі, що відтворюють загальні принципи 
досліджуваних явищ. Ключовий психологічний елемент - “способи діяльності" (В.В. Давидов, С.Д. Максименко).

Для нас цікавими $\epsilon$ підходи до визначення місця моделі у поліізоморфних системах змісту технологій навчання М.I. Лазарєва [12]. Вихідними даними для розробки поліізоморфного змісту технологій навчання є: дидактичні цілі; цілі розвитку професійно важливих якостей фахівців; опис декларативних і процедурних знань, які відображають стан розвитку відповідної діяльності.

У результаті процесу розробки мають бути сформовані поліізоморфні лінійні моделі навчальних елементів (моделі репрезентації систем знань).

Важливим є визначення змісту підготовки, основу якого складає модель здобувачів вищої освіти ступеня доктора філософії у ад'юнктурі: узагальнений перелік якостей, що передбачає наявність професіоналізму у відповідній сфері діяльності. Дана модель є еталоном, який дозволяє знайти ступінь наближення до бажаного рівня професіоналізму. Це узагальнений ідеал професіонала, досягнення якого $є$ основною метою діяльності вищої школи і відповідає всім вимогам практики 3 урахуванням тих змін, що прогнозуються в недалекому майбутньому. Вона узагальнює у певну систему, характерні саме для цього виду діяльності, особистісні якості, компетентності та компетенції, що забезпечують ії функціонування в будьяких умовах.

За А.О. Лігоиьким, сама модель має визначати програму організації та розвитку процесу підготовки... [13, с. 73]. Модель здобувачів вищої освіти ступеня доктора філософії у ад’юнктурі виконує дуже важливі функції при встановленні структури і взаємозв'язків, необхідних видів знань і навичок, визначенні якісних і кількісних параметрів необхідної інформації, а також методів її передачі й засвоєння. Структура моделі має не тільки відображати вимоги $з$ фаху, передбачати багатоступеневе підвищення його кваліфікації, а й забезпечувати ідейну, економічну, правову, загальнонаукову, теоретичну i професійну підготовку.

Для більш грунтовного опрацювання дидактичних умов необхідно деталізувати дану категорію та уточнити сутність і зміст поняття “модель здобувачів вищої освіти ступеня доктора філософіі”. У це поняття дослідниками вкладається різний зміст. Більшість науковців (I. Хейстер, Ф. де П. Ханіка, Р. Акоф $\phi)$ розуміє під цією моделлю описовий аналог, що відображає основні характеристики об'єкта, яким $\epsilon$ узагальнений образ фахівця даного профілю. Таке розуміння не суперечить філософському визначенню моделювання як “відтворення характеристик певного об'єкта... на іншому об'єкті, спеціально створеному для їх вивчення” [14, с. 381].

I.I. Сігов зазначав: "Модель фахівця представляється можливим трактувати як образ, яким він повинен бути на певний період часу, виражений певною документацією. Модель фахівця, насамперед, містить у собі його паспорт як описання об'єктивних вимог до нього, своєрідного державного стандарту..." [15, с. 56]. 
Інший зміст вкладає в це поняття Ю.О. Лавріков. На його думку, модель - це відображення навчальних планів, програм та інших документів, у яких описується і регламентується процес підготовки фахівців у вищій школі. Модель підготовки фахівців у найбільш загальному вигляді представляє собою схематичне вираження обсягу та структури соціальних, спеціальнопрофесійних, організаційно-управлінських, морально-етичних знань, якостей і навичок, необхідних фахівцю для трудової діяльності. Якщо прийняти таке визначення, то слід вважати, що моделі фахівців існують давно, а нині мова йде тільки про їхні зміни, доповнення та вдосконалення.

Але виникає запитання: як поєднати наявну модель з реальним станом у певній сфері діяльності? Подальші роздуми Ю.О. Лаврікова дають ключ до розуміння цієї ситуації. Він зазначав, що: "Побудова моделі передбачає встановлення: а) функціональної сутності фахівця; б) широти його професійного профілю; в) професіологічних характеристик; г) експертних оцінок і прогнозів розвитку цієї діяльності на найближчу та віддалену перспективу; д) схеми навчальних дисциплін з урахуванням їх об'єму та співвідношення" [16, с. 74].

Аналізуючи вищезазначене, можна зробити висновок про необхідність поєднання цих двох підходів. Ми вважаємо, що, по-перше, модель виступає як існуючий навчально-виховний комплекс, який коригується i вдосконалюється на основі вимог практики; по-друге, вимоги практики знаходять своє відображення у даних щодо практичної діяльності фахівців, їхніх професійних якостей, тенденцій розвитку сфери їхньої професійної діяльності тощо.

Тлумачення моделі здобувачів вищої освіти ступеня доктора філософії у ад'юнктурі 3ВО, що містить одночасно і визначення моделі в описовій формі, i технологію іiі побудови, розглядається науковцями в різних модифікаціях. Наприклад, I.M. Хейстер вважав, що “оптимальний план підготовки може бути складений лише на підставі моделі знань випускника, яка повинна розроблятися 3 урахуванням думки підприємств", тобто створюється “модель знань” і пропонується спосіб отримання відомостей для іiї конструювання - збір і аналіз “думок” [16, с. 17]. Існують також інші точки зору, прихильники яких включають у визначення моделі, крім знань, також і вміння фахівця, його особистісні якості й інші характеристики $[17$, с. 182$191 ; 18$, c. $4-7 ; 19$, c. $29-35]$.

На нашу думку, концепція, згідно 3 якою за модель приймаються безпосередньо плани підготовки, програми та інші документи, що регламентують дидактичний процес, не зовсім коректна, оскільки вона не передбачає вивчення професійної діяльності фахівця. Найбільш оптимальною і в прикладному аспекті корисною $є$ концепція, в якій в основу моделі здобувачів вищої освіти ступеня доктора філософії у ад'юнктурі покладена модель їх професійної діяльності як на теперішній час, так і на перспективу. Критерієм обгрунтованості цієї концепції виступає практика з іiі існуючими і перспективними вимогами. Адже саме під таким кутом зору 
виявляються суттєві недоліки сучасної підготовки, що також є перевагами концепції.

Моделювання професійної діяльності здобувачів вищої освіти ступеня доктора філософії в ад’юнктурі дає можливість ширше глянути на завдання підготовки і використання НП та НПП, оцінювати якість роботи різних ланок навчального закладу, визначити основні компетенції військово-професійної діяльності, опираючись на які в ВЗВО можна організувати i планувати процес підготовки на кафедрах для досягнення оптимального результату у вигляді компетентного доктора філософії.

Передбачається, що цей процес знаковий, емпіричний, в основі його аналіз військово-професійної діяльності відповідних фахівців і умов, які їх оточують (соціального і професійного фону), що, 3 одного боку, охоплює найбільш суттєві характеристики, а 3 другого - відповідає вимогам, які висуваються до моделей, використовуваних при аналізі соціальних процесів.

Проблему моделі професійної діяльності здобувачів вищої освіти ступеня доктора філософії у ад'юнктурі ВЗВО можливо розглядати в різних аспектах: конструювати 3 урахуванням практичних здібностей чи інтелектуальних достоїнств; розглядати цю проблему у відношенні фахівець - суспільство, чи, нарешті, 3 погляду функції керівника як організатора. Викладені вище теоретичні положення $€$ концептуальною основою обгрунтування моделювання професійної діяльності здобувачів вищої освіти ступеня доктора філософії у ад'юнктурі.

Кінцевою метою підготовки здобувачів вищої освіти ступеня доктор філософії у ад'юнктурі ВЗВО, яка заснована на принципах гуманізму та гуманітаризації, повинно стати виховання не лише військового професіонала, а насамперед суспільно активної свідомої особистості. Виходячи 3 вищесказаного, основними шляхами іï досягнення є: впровадження сучасних технологій та наукових досягнень, усунення уніфікації освіти й авторитарної педагогіки, підготовка нової генерації кадрів.

Висновки та перспективи подальших досліджень. Отже, актуальною $\epsilon$ проблема орієнтації НПП щодо моделювання процесу підготовки на усі основні сфери людської сутності: смислову та ціннісну (життєві принципи, домінантні цінності на основі загальнолюдських, національних і військовопрофесійних ідеалів), інтелектуальну (розвиток інтуїції, абстрактного, практичного та логічного мислення, пам'яті, загального і професійного інтелекту тощо), емоційно-вольову (розвиток емоційної культури, вольових якостей), фізичну (загартовування). Різнобічна і фундаментальна підготовка може бути досягнута також тим, що у ряді провідних 3 ВО як військових, так і цивільних - склалися наукові школи досить високого рівня. Все це буде сприяти створенню мобільної сучасної армії, в чому сьогодні відчувається нагальна потреба.

Моделювання діяльності здобувачів вищої освіти ступеня доктора філософії у ад'юнктурі ВЗВО в умовах посилення професіоналізації військової служби стане одним із ефективних засобів покращення підготовки 
офіцерів до майбутньої військово-професійної діяльності. У педагогіці більше, ніж в інших галузях науки, потрібен діалектичний підхід: пошук нового, оновлення старого, використання кращого досвіду, відмова від того, що себе не виправдало. Саме такий підхід зможе забезпечувати вибір оптимального шляху моделювання здобувачів вищої освіти ступеня доктора філософії у ад'юнктурі ВЗВО, реалізацію педагогічного принципу зв'язку навчання $з$ життям військ.

Подальшим розвитком основ моделювання професійної діяльності здобувачів вищої освіти ступеня доктора філософії, як їх практичної складової, є розробка "Методичних рекомендацій з організації підготовки здобувачів вищої освіти ступеня доктора філософії та доктора наук у вищих військових навчальних закладах (науково установах) Міністерства оборони України", що здійснюється на виконання рішення секції Воєнно-наукової ради Міністерства оборони України.

\section{ЛІТЕРАТУРА}

1. Закон України “Про вищу освіту”, від 1 липня 2014 року № 1556-VII.

2. Постанова Кабінету Міністрів України від 23 березня 2016 року № 261 “Порядок підготовки здобувачів вищої освіти ступеня доктора філософії та доктора наук у вищих навчальних закладах (наукових установах)" [Електронний ресурс]. - Режим доступу: ttp://www.kmu.gov.ua/control/uk/cardnpd?docid=248945529.

3. Наказ Міністерства оборони України від 24 лютого 2017 року № 115 “Особливості підготовки здобувачів вищої освіти ступеня доктора філософії та доктора наук у вищих військових навчальних закладах (науково-дослідних установах) Міністерства оборони України".

4. Постанова Кабінету Міністрів України. від 23 листопада 2011 р. № 1341 "Про затвердження Національної рамки кваліфікацій”. [Електронний ресурс]. - Режим доступу: ttp://www. zakon.rada.gov.ua/go/1341-2011-п.

5. Саркисян С.А., Голованов Л.В. Прогнозирование развития больших систем / С. А. Саркисян., Л. В. Голованов. - М.: Просвещение, 1975. - 346 с.

6. Серветник Р.М. Гуманістична парадигма, як основа моделювання процесу підготовки військових фахівців // Військова освіта: Зб. наук. пр. - К.: Наук.-метод. центр військової освіти МО України, 2005. - № (2)16. - С. 48-57.

7. Калапуша Л.Р. Моделювання у вивченні фізики. - К.: Рад. школа, 1982. - 154 с.

8. Крутов В.И., Грушко И.М., Попов В.В. Основы научных исследований. - М.: Высшая школа, 1989. - 400 с.

9. Лігоцький А.О. Теоретичні основи проектування сучасних освітніх систем. - К., 1997 - 207 c.

10. Архангельский С.И. Учебный процесс в высшей школе, его закономерные основы и методы. - М.: Высшая школа, 1980. - 360 с.

11. Кошманова Т. С. Розвиток педагогічної освіти у США (1960-1998 рр.). - Львів: Світ, 1999. - 484 с.

12. Лазарев М. I. Полісистемне моделювання змісту технологій навчання загальноінженерних дисциплін: Монографія. - Харків: Видавництво НФаУ, 2003. - 356 с.

13. Лігоцький А.О. Методологічні аспекти проектування сучасних освітніх систем. - К.: Преса України, 1995. - 107 с.

14. Философский энциклопедический словарь / Гл. редакция: Л.Ф. Ильичев, П.Н. Федосеев, С.М. Ковалёв, В.Г. Панов. - М.: Сов. Энциклопедия, 1983. - 381 с. 
15. Сигов И.И. О методике разработки модели специалиста (на примере инженерно-экономических специальностей) // Проблемы совершенствования высшего образования. - Л., 1974. - 69 с.

16. Лавриков Ю.А. О модели профессиональной подготовки экономиста. Улучшение подготовки экономистов и экономической подготовки инженеров. - Л., 1973. -195 c.

17. Воловик П.М. Вивчення і моделювання структури успішності студентів 3 фізики // Педагогіка і психологія професійної освіти. - 1999. - № 5. - С. 182-191.

18. Зязюн І.А. Сучасні дидактичні моделі і логіка учення // Сучасні інформаційні технології та інноваційні методики навчання в підготовці фахівців: методологія, теорія, досвід, проблеми: Зб. наук. праць. - К. - Вінниця, 2000. - С. 4-7.

19. Сисоєва С.О. Теоретична модель підготовки вчителя до педагогічної творчості // Проблеми професійної підготовки та виховання: Збірник наукових праць. - К.: ТОВ “Міжнародна фінансова агенція”, 1998. - С. 29-35.

\section{REFERENCES}

1. Law of Ukraine “On Higher Education”, dated July 1, 2014 ,n.o. 1556-VII, available at: http//www.zakon.rada.gov.ua.

2. Resolution of the Cabinet of Ministers of Ukraine "Procedure for the training of higher education Doctor of Philosophy and Doctor of Science candidates at higher educational institutions (scientific institutions)" as of March 23, 2016, n.o. 261, available at: http//www.zakon.rada.gov.ua.

3. Order of the Ministry of Defense of Ukraine "Features of training of higher education Doctor of Philosophy and Doctor of Science candidates at higher military educational institutions (scientific and research institutions) of the Ministry of Defense of Ukraine" as of February, 2017, n.o. 115, available at: http//www.zakon.rada.gov.ua.

4. Resolution of the Cabinet of Ministers of Ukraine dated November 23, 2011 No. 1341 "On Approval of the National Qualifications Framework". [Electronic resource]. - available at ttp://www.zakon.rada.gov.ua/go/1341-2011-en.

5. Sarkysian, S. A., Golovanov, L. V. (1975). Prognozirovanie razvitiya bolshih sistem [Prognosis of the development of large systems]. Moscow, Russia: Enlightenment, 346.

6. Servetnyk, R. M. (2005). GumanIstichna paradigma, yak osnova modelyuvannya protsesu pIdgotovki vIys'kovih fahIvtsIv [Humanist paradigm as a basis for modeling the training of military specialists]. Military education: collection of scientific works. Kiev, Ukraine: Scientific method. Center for Military Education of the Ministry of Defense of Ukraine, (2) 16, 48-57.

7. Kalapusha, L. R. (1982). Modelyuvannya u vivchennI fIziki [Modeling in the study of physics]. Kiev, Ukraine: Rad. school, 154.

8. Krutov, V. I., Grushko,I. M., Popov,V. V. (1989). Osnovyi nauchnyih issledovaniy [Fundamentals of scientific research]. Moscow, Russia: Higher school, 400.

9. Lihotskyi, A. O. (1997). Teoretichni osnovi proektuvannya suchasnih osvitnih sistem [Theoretical Foundations of Designing Modern Educational Systems]. Kiev, Ukraine: 207.

10. Arkhanhelskyi, S. I. (1980). Uchebnyiy protsess v vyisshey shkole, ego zakonomernyie osnovyi i metodyi [The educational process in the higher school, its regular principles and methods]. Moscow, Russia: Higher school, 360.

11. Koshmanova, T. S. (1999). Rozvitok pedagogichnoyi osviti u SShA (1960-1998 rr.) [Development of pedagogical education in the USA (1960-1998 gg.)]. Lviv, Ukraine: World, 484.

12. Lazarev, M. I. (2003). PolIsistemne modelyuvannya zmistu tehnologiy navchannya zagal'noinzhenernih distsiplin [Polysystem modeling of content of training technologies of general engineering disciplines]. Monograph. Kharkiv, Ukraine: Publishing House of NFaU, 356. 
13. Lihotskyi, A. O. (1995). MetodologIchnI aspekti proektuvannya suchasnih osvItnIh sistem [Methodological Aspects of Designing Modern Educational Systems]. Kiev, Ukraine: Press of Ukraine, 107.

14. Ilyichev, L. F., Fedoseev, P. N., Kovalev, S. M., Panov, V. G. (1983). Filosofskiy entsiklopedicheskiy slovar [Philosophical Encyclopedic Dictionary]. Moscow, Russia: Sov. Encyclopedia, 381.

15. Sihov, I. I. (1974). O metodike razrabotki modeli spetsialista (na primere inzhenernoekonomicheskih spetsialnostey) [About the methodology of developing a model of a specialist (on an example of engineering and economic specialties)]. Problems of perfection of higher education, Leningrad, Russia: 69.

16. Lavrikov,Y. A. (1973). O modeli professionalnoy podgotovki ekonomista. Uluchshenie podgotovki ekonomistov i ekonomicheskoy podgotovki inzhenerov [About the model of professional training of an economist. Improvement of preparation of economists and economic training of engineers]. Leningrad, Russia: 195.

17. Volovyk, P. M. (1999). Vivchennya i modelyuvannya strukturi uspishnosti studentiv $\mathrm{z}$ flziki [Studying and modeling the structure of students progress in physics]. Pedagogy and psychology of professional education, 5, 182-191.

18. Ziaziun, I. A. (2000). Suchasni didaktichni modeli i logika uchennya [Modern didactic models and the logic of teaching]. Modern information technologies and innovative methods of training in the training of specialists: methodology, theory, experience, problems: Collection of scientific works. Vinnytsya, 4-7.

19. Sysoeva, S. O. (1998). Teoretichna model pidgotovki vchitelya do pedagogIchnoyi tvorchosti [Theoretical model of preparation of teacher for pedagogical creativity]. Problems of professional preparation and education: Collection of scientific works. Kiev, Ukraine: LLC "International Finance Agency", 29-35.

\section{РЕЗЮМЕ}

Владимир Колесник, кандидат технических наук, старший научный сотрудник

Руслан Серветник, кандидат педагогических наук, старший научный сотрудник, Национальный университет обороны Украины имени Ивана Черняховского

\section{Теоретические основы моделирования профессиональной деятельности соискателей высшего образования степени доктора философии в адъюнктуре военного заведения высшего образования}

В статье отображень теоретические основы моделирования профессиональной деятельности соискателей высшего образования степени доктора философии в адъюнктуре военного заведения высшего образования и возможные пути их решения при организаџии подготовки в военных заведениях выстего образования (научных учреждениях). Моделирование профессиональной деятельности соискателей высшего образования степени доктора философии в адъюнктуре военного заведения высшего образования дает возможность шире взглянуть на задачи подготовки и использования научных и научно педагогических работников, оченивая качество роботы различных подразделений учебного заведения, определить основные компетенции профессиональной деятельности для достижения оптимального результата.

Ключевые слова: заведения высшего образования; подготовки соискателей выстего образования степени доктора философии; нормативно-правовые документы; модели образования. 


\title{
SUMMARY
}

\author{
Volodymyr Kolesnyk, \\ Candidate of Technical Science, senior researcher, \\ Ruslan Servetnyk, \\ Candidate of Pedagogical Science, senior researcher, \\ National Defense University of Ukraine \\ named after Ivan Cherniakhovskyi
}

\section{Theoretical bases of modeling of professional activity of applicants of higher education degree of the doctor of philosophy in postgraduate of military institution of higher education}

Introduction: Modern trends in the development of the Armed Forces of Ukraine (hereinafter - AF of Ukraine), set new requirements for the training of applicants for higher education in the degree of doctor of philosophy, i.e. Ph.D. It means that simple accumulation of knowledge and skills is no longer satisfactory, but the training of a highly qualified military specialist of the corresponding of level and profile, competitive, competent, completely mastered a military profession and oriented in related fields of activity, ready for permanent professional growth, social and professional mobility is required.

According to the normative and legacy basis of Ukraine, the training of applicants for higher education in Ph.D. degree involves gaining the theoretical knowledge, skills and other competencies sufficient for the production of new ideas, solving complex problems in the field of professional and/or research and innovation activity. It requires mastering the methodology of scientific and pedagogical activity, as well as conducting own scientific research, the results of which have a scientific novelty, theoretical and practical value.

Purpose: is to explain the theoretical bases of modeling the professional activity of higher education Ph.D. graduates in the postgraduate study program; develop methodological and practical recommendations for the training of military personnel of higher qualification.

Methods of research: the method of analysis and synthesis and the method of expert evaluations are used.

Results: The ultimate goal of training doctors of philosophy graduates in the postgraduate study program in military institutions of higher education, based on the principles of humanism and humanization, should be education not only of a military professional, but also primarily of a socially active conscious personality. Proceeding from the foregoing, the main ways of its achievement are introduction of modern technologies and scientific achievements, elimination of unification of education and authoritarian pedagogy, preparation of a new generation of personnel.

Originality: Modeling the professional activity of higher education graduates of the Ph.D. degree in postgraduate programs gives an opportunity to look more broadly at the tasks of preparation and use of scientists and researchers. It important to assess the quality of work of different parts of an educational institution to determine the main competences of militaryprofessional activity, based on which one can to organize and plan the process of preparation at the departments to achieve the optimal result in the form of a competent doctor of philosophy.

Conclusion: The modeling of the degree of Ph.D. in the postgraduate study program in military institutions of higher education in the context of strengthening the professionalization of military service will be one of the effective means of improving the training of officers for future military-professional activities. In pedagogy, more than in other fields of science, a dialectical approach is needed: the search for new things, the renewal of the old, the use of best practices, and the rejection of what was not justified.

Key words: institutions of higher education; training for applicants of higher education of the degree of Doctor of Philosophy; normative and legal documents; models of education. 